\title{
EMPLOYEE LEARNING AND DEVELOPMENT IN ORGANISATIONS
}

\section{Lucie Vnoučková}

\section{Abstract}

The primary goal of all organisations is efficiency of human resources. Therefore activities as HR controlling, performance management but also cutting costs are the main theme. Current organisations need to monitor human resources to keep their competitiveness. Thus paper describes the key factor of organisational efficiency - employee education, talent management and the necessity to retain skilled employees. The aim of the paper is to reveal the current approach in organisations to education and learning based on primary survey of employees. The data were collected using quantitative primary survey in Czech organisations across sectors. The questionnaire was compiled based on the theoretical background. The paper has been processed based on the analysis of secondary sources, outcome synthesis and the evaluation of results of a questionnaire survey. The data were analysed using descriptive statistic, correlation analysis and factor analysis. The SPSS programme was used for the analyses. The outcomes were categorized and the analyses revealed the main factors affecting organisational approach to employee learning and development. The results identify three possible approaches in organisations to employee learning and development. The first type of organisations educates employees by their own rules, second type does not support education of employees in any way, it is only an interest of employees themselves and thirdly knowledgeable employees were identified as those employees do as much
The University of Economics and Management

lucie.vnouckova@vsem.cz

ARTICLE INFO

Article type

Full research paper

doi: 10.7160/eriesj.2013.060305

Article history

Received: August 10, 2013

Received in revised form: August 27, 2013

Accepted: September 3, 2013

Available on-line: September 30, 2013

as possible to learn and grow and they choose job position in order to develop constantly. The results can be taken into account in further analysis and in organisation of adult education.

\section{Key Words}

Development, efficiency, employee, learning, organisation, talent 


\section{Introduction}

To keep and develop quality knowledgeable employees is the main goal of all organisations. The only thing that really matters in order to increase the level of organisations and economy is human resources and their management and development. Therefore organisations should focus on education and learning of each individual. It is also necessary to educate and develop employees in order to their work and social values and behaviour - each employee is individuality with different perception and personality. Organisations should focus on specifics of their employees in order to set effective goals of education, learning and training of employees. Employees who are educated and developed are usually highly interested in organisational goals, strategy; they are communicative, cooperative and proactive, respectful, customer-friendly, willing and able to constantly learn. As Mazouch and Fischer (2011) stated, measurement of education level in organisations is necessary to prognosis of future development. Therefore, paper focuses on employee education and approaches to employee education and learning both by Czech organisations and also by employees themselves. The aim of the paper is to reveal the current approach in Czech organisations to education and learning based on primary survey of employees.

Vostrá, Jindrová and Dömeová (2011) and Zeman (2009) state that it is necessary to care for employees in the way of education and development, otherwise there is a possibility that organisation will lose those employees. The necessity to keep educated, trained and skilled employees is also registered by European Union. Vostrá, Jindrová and Dömeová (2011) mentioned key indicators of Lisbon Strategy, which focus mainly on sustainability of employees and employment. It is the priority of the whole Europe, which is focused on people and knowledge. The main priority of knowledge society till the year 2020 is namely productivity, education and employment and their impact on development of Europe. Mráček (2009) highlights that current economic crisis brought lowering of new products and services, new patents and also lowering of expenditure on research, development and education. But lowering of expenditure on research, development and education cause lowering of new products, services, and patents. If an organisation cut expenditure on education and learning, the productivity, innovation and thus ability to attract customer will be also lower. This phenomenon supports the need of education, learning and care for knowledgeable and skilled employees. Additionally, Mráček (2009) notes that if organisations lower their expenses on education and learning, they make a strategic mistake, because the best employees are no longer motivated to work in organisation. This results into weakening of the whole organisation which is not ready for recovery of economy and thus it is real threat to competitiveness. Q1: Is education and learning supported by Czech organisations?

Although the main motivation principles were defined many times by many authors, we may still describe them as considerable simplified, as Chwaszcz (2011) mentioned. The author stated that reality brings much more variables which cause deviation from theory and also that employee is not always rational. Ramlall (2004) in his study identified factors leading to work satisfaction. Firstly it was basic needs according to Maslow (1943) secondly equality, thirdly filled expectation and finally concept of job position. Studies resulted into low correlation between dissatisfaction with remuneration; on the contrary, organisations were suggested to focus on increasing of qualification and competencies of employees and obviousness meaning of their work. Therefore it is necessary to change 
the way of cooperation between employees and managers. Managers should focus on new competencies and behaviour according to use of employee as a person, not just work unit (Königová and Fejfar, 2011). Competencies and competence models represent a possibility to unify needs of organisation with abilities of employees and their education and growth. According to Peters (2011) and Vronský (2012) emphasis should be placed on managers who would be able to work with employees in certain way.

Q2: Are employees motivated to education and learning by Czech organisations?

Peters (2011) highlights soft factors in organisations. He states that intangible trivia determines the final employee satisfaction, their possible grow and willingness to learn and grow. Covey (2011) and Peters (2011) also states that it is necessary for future development of employees and organisation to use sustainable values which will lead to sustainable development. Namely: cooperation, ethics, integrity (relationships) and quality and values for the next generation. Authors argue that the main decisions which proved to be right and persisting (and authors have shown many examples proving such statement) are often not according to economic, financial and other analysis (which, according to Peters (2011) caused current crisis), but based on abilities of employees, their character, relationships and common values (cooperation, sacrifice, listening and orientation on goals, results, needs and customer as person and citizen).

Q3: Can education and learning be considered as long term concept in Czech organisations?

Stated questions will be evaluated based on primary outputs in the end of results of the paper.

\section{Materials and Methods}

The data for the evaluation of current education and learning in Czech organisations has been collected in primary quantitative survey by means of questionnaire investigation. Questionnaire was completed by 110 employees across sectors. The method used for the collection of data was an electronic questionnaire that automatically recorded and pre-categorised respondents' answers (CAWI method). The selection of a representative sample of employee population across sectors was carried out by a random selection of e-mail addresses, which incorporates the advantages of multilevel random selection (Disman, 2008). In total, 1122 e-mails including questionnaire were send to Czech organisations in January and February 2013. The sample was selected solely for the purposes of the survey. Answers of respondents were categorised according to identification questions that formed the first part of the questionnaire. In the survey, the measurement was based on closed questions with one or several possible answer(s) that had been selected based on the study of literature, documents and other related surveys carried out by the following authors: Colvin (2010), Maxwell (2012), Horváthová (2011), Knight (2011) and Vronský (2012). The methods used in the study were inspired by Meyer and Allen, (1991), Gosling, Rentfrow and Swann (2003), John, Naumann and Soto (2008), Anderson (2009), Michela (2007), Jablonský (2011) and Xin et al. (2011). Also, a semantic differential was applied that permitted the identification of nuances in respondents' attitudes through the questionnaire. Respondents' reactions to target statements and their attitudes to the given matter were restricted by offering a set of several statements (Hayes, 1998). The extremes of the seven-point scale represented bipolar concepts of the evaluation dimension. Using a scale of 1 to 7 , respondents expressed their inclination towards one of 
the pre-set extreme statements or, provided it was not possible to favour either of the sides, selected a median, neutral value (the median value was characterised by number 4 ). The scale permitted not only the specification of respondents' attitudes, but also their intensity. The respondents were mainly (51\%) from small organisations (till 50 employees), $24 \%$ were from medium sized organisations and $26 \%$ from large organisations (over 250 employees). Age of the respondents was mainly until 30 years (47\%), between 30 and 40 years were $27 \%$ and over 40 years were $26 \%$ of respondents. The analysis was carried out using the Microsoft Excel 2007, and SPSS programmes. The conclusiveness of the outputs and relationships obtained were supported by the tools of descriptive statistics, for testing of results the analysis of correlation and factor analysis were used to review the outcomes.

\section{Results}

Bellow in this chapter, main results will be interpreted. Firstly, the overall situation in Czech organisations will be presented. Secondly, deeper analyses (correlation, association and factor analysis) will give us insight view into organisational practices in education and learning.

\section{Education and learning in Czech organisations}

The surveyed employees are willing to be educated and they would like to use such opportunity. $95.5 \%$ of respondents want to grow in their current job position. That is a good sign for organisations, because the motivation of employees is overall high and thus it is easier to work on education and training of such employees. As theory states, the internal motivation is the key to effective education of adults (Knight, 2011; Colvin, 2010). Current employees perceive modern trend of necessity of flexibility and therefore they want to use any possibility to grow (Vostrá, Jindrová and Dömeová, 2011). Employees also know that job position is usually not for a life time and they want to explore their skills and knowledge to be successful in their profession whether in current position or the next one (Linhartová, 2012a).

But employees stated that they were motivated for education and learning by long-term intangible rewards only in $37 \%$. On the contrary, $44 \%$ of employees have no support from organisation. Almost the same results were found by focusing on tangible rewards (money and benefits). 33\% of organisations support education and learning in mentioned way, on the other hand $56.5 \%$ of organisations do not reward education at all. Colvin (2010) stated, that tangible rewards (such as salary, money and benefits) are contra productive to motivation to learn, therefore this result will be discussed further in deeper analyses (twodimensional - correlation analysis and multidimensional factor analysis).

Quite positive results we get regarding to a specific knowledge educated in organisations. Almost $66 \%$ of employees stated that their education and learning in organisation is focused on a specific skills related to their work. Surveyed employees also evaluate their job positions as a place where they can grow and they have chosen this position because of this possibility (in 89\%). Mostly, the position was chosen in the area of future interest $(82 \%)$ and surveyed employees show their own initiative in order to learn and grow (95.5\%), which supports the motivation to self-development, learning and study. This concept proves the result that $70 \%$ of employees study and work on their development also at home (but still there are $21 \%$ of employees demotivated, who do not want to do anything else than necessary and they are not willing to offer their free time). 
Education and learning is a part of job in $66.5 \%$ of organisations according to results of the questioning; and in $73 \%$ employees have set a specific goal (together with their manager or supervisor) to achieve in learning and growth process. Organisational learning and education also seems to be a longterm process. $63 \%$ of evaluated employees see their education and learning as long-term process. Short-term goals and only single-purposed training or courses are used in $23 \%$ of organisations.

Overall, results revealed that most of the employees are willing to be part of education and learning process and they know about its necessity. Positive results were found that employees are mainly self-motivated and they are trying to find new ways to grow.

\section{Associations between organisational practices related to learning and development}

Previous chapter explained the overall situation in surveyed organisations. Therefore association analysis was used to found statistically significant relationships and similarities in usage of searched practices connected to learning and development of employees in organisations. For the association analysis Pearson's coefficient and Spearman's rho was used. Both analyses have shown similar results. Regarding the fact that there were 12 variables entering the analysis, the names of variables are coded (explanation of codes is in the Tab. 3) and the results are reduced in the Tab. 1 bellow. Marked are statistically significant correlations/associations. Double star means significance level of 0.01 and one star means significance level of 0.05 .

\begin{tabular}{|c|c|c|c|c|c|c|c|c|c|c|c|c|}
\hline & A & B & C & D & $\mathrm{E}$ & $\mathrm{F}$ & G & $\mathrm{H}$ & I & $\mathrm{J}$ & K & L \\
\hline A Pearson & 1.00 & $.43^{* *}$ & .19 & .13 & $.38^{* *}$ & .10 & .15 & -.10 & -.00 & -.11 & $.20^{*}$ & .16 \\
\hline A Spearman & 1.00 & $.45^{* *}$ & $.22^{*}$ & $.21^{*}$ & $.49^{* *}$ & .14 & .14 & -.18 & -.04 & -.17 & $.26^{* *}$ & $.21^{*}$ \\
\hline B Pearson & & 1.00 & $.37^{* *}$ & $.31^{* *}$ & $.27^{* *}$ & .15 & .14 & .12 & $.24^{*}$ & $-.19^{*}$ & .08 & .19 \\
\hline B Spearman & & 1.00 & $.31^{* *}$ & $.23^{*}$ & $.29^{* *}$ & $.26^{* *}$ & $.19^{*}$ & .08 & $.21^{*}$ & -.14 & .14 & $.27^{* *}$ \\
\hline C Pearson & & & 1.00 & $.66^{* *}$ & $.27^{* *}$ & $.27^{* *}$ & $.43^{* *}$ & $.41^{* *}$ & $.49^{* *}$ & .00 & $.41^{* *}$ & .06 \\
\hline C Spearman & & & 1.00 & $.58^{* *}$ & $.26^{* *}$ & $.23^{*}$ & $.36^{* *}$ & $.43^{* *}$ & $.49^{* *}$ & -.03 & $.36^{* *}$ & .07 \\
\hline D Pearson & & & & 1.00 & $.22^{*}$ & $.27^{* *}$ & $.64^{* *}$ & $.32^{* *}$ & $.46^{* *}$ & -.01 & $.43^{* *}$ & .11 \\
\hline D Spearman & & & & 1.00 & $.23^{* *}$ & $.25^{* *}$ & $.545^{* *}$ & $.28^{* *}$ & $.40^{* *}$ & -.06 & $.43^{* *}$ & .14 \\
\hline E Pearson & & & & & 1.00 & $.36^{* *}$ & .14 & .09 & $.30^{* *}$ & -.10 & $.26^{* *}$ & $.45^{* *}$ \\
\hline E Spearman & & & & & 1.00 & $.35^{* *}$ & $.20^{*}$ & .03 & $.24^{*}$ & -.18 & $.34^{* *}$ & $.38^{* *}$ \\
\hline F Pearson & & & & & & 1.00 & $.38^{* *}$ & $.20^{*}$ & $.27^{* *}$ & -.05 & $.21^{*}$ & $.36^{* *}$ \\
\hline F Spearman & & & & & & 1.00 & $.33^{* *}$ & .13 & $.22^{*}$ & -.03 & .18 & $.43^{* *}$ \\
\hline G Pearson & & & & & & & 1.00 & $.35^{* *}$ & $.44^{* *}$ & .06 & $.45^{* *}$ & .18 \\
\hline G Spearman & & & & & & & 1.00 & $.34^{* *}$ & $.39^{* *}$ & .01 & $.41^{* *}$ & .17 \\
\hline H Pearson & & & & & & & & 1.00 & $.77^{* *}$ & .06 & $.25^{* *}$ & .08 \\
\hline H Spearman & & & & & & & & 1.00 & $.78^{* *}$ & .11 & $.21^{*}$ & .02 \\
\hline I Pearson & & & & & & & & & 1.00 & .03 & $.33^{* *}$ & .16 \\
\hline I Spearman & & & & & & & & & 1.00 & .06 & $.29^{* *}$ & .09 \\
\hline J Pearson & & & & & & & & & & 1.00 & -.01 & -.07 \\
\hline J Spearman & & & & & & & & & & 1.00 & -.08 & -.12 \\
\hline K Pearson & & & & & & & & & & & 1.00 & $.20^{*}$ \\
\hline K Spearman & & & & & & & & & & & 1.00 & $.23^{*}$ \\
\hline
\end{tabular}

Tab. 1 Association analysis of surveyed variables

The Tab. 1 shows that some of the selected variables are interconnected. Both analyses (Pearson's and Spearman's) gave similar results.

With the willingness of the employees to grow (A) correlates the selection of the job in order to learn constantly (B), that employee is motivated by his/her own initiative (E) and employee is practicing also at home. This indicates really knowledgeable and talented employee. We may say that this correlation indicates 
the best possible approach to learning and development. It is an internally motivated and self-driven attitude. To keep this kind of employee in an organisation is a crucial factor of efficiency.

With the selection of job position in order to learn (B) is associated the statement that learning and development is supported by the organisation (C), it is focused on specific skills (D), employee is internally motivated (E), he/she works in his/her area of interest (F) by Spearman's coefficient, also that learning is supported by intangible benefits and Spearman's coefficient also indicated that it is a long term attitude. Here it is possible to see a combination between internal motivation of an employee and support of an organisation. It is a good coincidence. Employee is willing to learn and to be developed and chooses his/her job position in order to fill this goal. As we may see, organisation supports long term development and focuses on long term support to increase employee's motivation by intangible benefits.

The statement that learning is supported by organisation (C) is associated with focus on specific skills (D), employee's internal initiative (E), work in the area of own interest $(F)$, development is a part of the job $(\mathrm{G})$, learning is rewarded $(\mathrm{H})$ and supported (I) and employee is practicing at home $(\mathrm{K})$. It is possible to describe this approach as cooperation between employee and organisation. Both parts are willing to develop employee's knowledge and skills. But the disadvantage of this approach is that it has not a specific goal and it is mainly only a singlepurpose learning (not a long-term process).

The variable stating that learning and development are focused on specific skills correlates almost with all other variables except that the learning and development has a specific goal (J), it is a long term process (L) and surprisingly only weak association was found by only Spearman's coefficient with internal willingness of employee to grow (A). This indicates that only the organisation is willing to develop their employees, but sometimes the way of forcing them will not be the best. Anyway, the lack of self-motivated and talented employees can be observed here.

The statement that development is an employee's internal initiative and he/she is motivated to constantly learn and selfdevelopment (E) correlates again almost with all other statements apart from the variables that learning is a part of job (only weak and not so significant correlation - G), than we may say that learning is not rewarded $(\mathrm{H})$ and it has not a specific goal $(\mathrm{J})$. The mentioned association revealed talented, knowledgeable employee who is not supported by organisation. It is a question, for how long this situation will continue. The employee knows about the necessity to learn and self-development, but the current conditions are not supportive. It is possible to expect this employee to change his/her job position in short period of time. The shift to a better job position is expected (Linhartová, 2012a).

The statement characterising employee, who works in his/her area of interest (F), also correlates with most of other statements. But surprisingly there is no connection between willingness to grow $(\mathrm{A})$, partly with choosing the job position in order to learn (B), learning is not usually rewarded $(\mathrm{H})$, it has not a specific goal (J) and employee does not want to sacrifice his/her free time to practice at home $(\mathrm{K})$. Here we may see just a job position which was chosen in the area of interest, this type of employees like what they do, but they are not willing to be educated and developed. If they are, it is only an organisational goal.

Learning and development as a part of job $(G)$ is associated again with most of organisational practices which are focused on employee's development. This type of employees again 
are neither interested in self-development (A), nor chosen job position to learn, they do not have a set goal to learn $(\mathrm{J})$ and it is not a planned process (L). As the previous type, these kinds of employees only follow the organisational rules, but they are not against it.

In the similar way it is possible to evaluate the statement that learning is rewarded (by money $-\mathrm{H}$ ). This statement correlates with support from an organisation (C), focus on specific skills (D), part of job (G), support by intangible benefits (I) and the need to practice at home $(\mathrm{K})$. Here it is possible to find really supportive and knowledge-oriented organisation, but the employees are not internally motivated and interested.

On the other hand, completely different attitude we may find when looking at the correlations connected to the support by intangible benefits (I). Employees are in tis case motivated (E), choose job because of the possibility to learn in an organisation which set specific goals to develop them (B, C, D, G and H), employee likes what he/she does $(\mathrm{F})$ and has no problem to practice at home $(\mathrm{K})$. These results strongly support the assumption by Colvin (2010) that intangible rewards supports learning and development but tangible rewards (money) result in the opposite attitude. Here we may see it works in that way.

Completely independent is the statement that learning has a specific goal (J). Basically no correlations can be found here. Thus it is possible to say that goals do not primary affect organisational learning.

On the contrary, when an employee is willing to practice at home $(\mathrm{K})$, it is a good sign. He/she is interested in development (A), they usually work in an organisation which support learning and development $(C, D, G)$, it is also supported $(H$, I) and employee is internally motivated (E). Again, here it is possible to recognize talented and knowledgeable employee.
To evaluate the time schedule of learning and development (L) we may also support the premise of Colvin (2010) that only those, who are real talents knows the rule that it is up to them to work on their development the whole their life (long-term) and in their free time (K), be self-motivated (E) and work in the area of their interest $(\mathrm{F})$.

Summary, we may say that the most of the statements are inter correlated. But as it was explained above, the correlations have a specific meaning and it reveals different approaches to employee learning and development. It is possible to find self-motivated employees and also supportive organisations which try to develop their employees and cooperation of both sides. However sometimes the organisation invest much more than it is possible to gain back from the employees' development. Still, the good result is that it is possible to find talents and knowledgeable employees in the population. Also, the assumption that intangible rewards supports and develops learning and development and tangible rewards (money) works in the opposite direction - demotivation was found in the results of the analysis.

\section{Factor analysis of approach to education and learning}

Based on the results, which have shown requisite level of correlation/association coefficient between analysed variables and revealed different attitudes to employee and organisational learning and development, a deeper analysis was used. In order to lower the amount of resulted outputs, the factor analysis was chosen. Varimax rotation method was used for analysis. The same characteristics were used for analysis, as were described above in previous chapter. As shown in Tab. 2, factor analysis revealed 3 statistically significant factors. To separate final amount of output factors a Kaiser-Guttman rule was employed. 
Such factors were used for further analysis, whose variance was higher than 1.0. This value was chosen rationally because explanatory factor must have at least equal value as original standardised attribute. Such attributes (statements) were chosen as significant to create resulted factor, whose value was 0.3 and higher (Anderson, 2009).

\begin{tabular}{|l|c|c|c|}
\hline & Total variance & \% of Variance & Cumulative $\%$ \\
\hline Factor 1 & 3,926 & 32,714 & 32,714 \\
\hline Factor 2 & 1,771 & 14,759 & 47,474 \\
\hline Factor 3 & 1,215 & 10,121 & 57,595 \\
\hline
\end{tabular}

Tab. 2: Variance explained by factors

All factors together explain 58\% of employee behaviour and attitude to education and learning. Tab. 3 show results of analysis by the Varimax method; Tab. 3 gradually show all factors and its attributes.

Factor analysis revealed three approaches to organisational learning and education in Czech organisations. First factor, which characterize one third of respondents can be described as learning and education which is a part of organisational culture. Employees stated, that learning and education is supported by organisation, it is focused on specific skills and knowledge, learning is rewarded (by tangible and also intangible) rewards, there is a specific goal of education and learning and also that education and learning is a part of their job. Therefore we may say that this kind of education and learning has a strong core in organisational culture and employees have to follow the organisational rule in order to fill the specific conditions focused on continuous learning. It is possible to notice, that those kind of employees are not always motivated by themselves or they did not choose the job because of the possibility to learn and grow, they are not willing to practice at home or do anything else than necessary inside an organisation. Thus it is possible to conclude that it is primary the organisation which is concentrated on learning and education.

\begin{tabular}{|c|c|c|c|c|}
\hline Code & Explanation of code - variable & $\begin{array}{c}\text { Factor } \\
1\end{array}$ & $\begin{array}{l}\text { Factor } \\
2\end{array}$ & $\begin{array}{c}\text { Factor } \\
3\end{array}$ \\
\hline A & Employee wants to learn and grow & 0.051 & 0.160 & 0.771 \\
\hline $\mathrm{B}$ & Employee chosen job as a possibility to learn & 0.287 & 0.049 & 0.715 \\
\hline $\mathrm{C}$ & Learning \& edu. is supported by org. & 0.773 & -0.007 & 0.286 \\
\hline $\mathrm{D}$ & Learning \& edu. is focused on spec. Skills & 0.789 & 0.014 & 0.233 \\
\hline $\mathrm{E}$ & Employee is motivated by own initiative & 0.166 & 0.691 & 0.361 \\
\hline $\mathrm{F}$ & Employee works in his/her area of interest & 0.298 & 0.663 & -0.005 \\
\hline G & Learning \& education is part of work/job & 0.717 & 0.173 & 0.026 \\
\hline $\mathrm{H}$ & $\begin{array}{l}\text { Learning \& edu. is rewarded (money, } \\
\text { benefits) }\end{array}$ & 0.732 & 0.102 & -0.292 \\
\hline I & $\begin{array}{l}\text { Learning \& edu. is supported (intangible } \\
\text { rew.) }\end{array}$ & 0.790 & 0.218 & -0.125 \\
\hline $\mathrm{J}$ & Learning \& education has specific goal & 0.552 & 0.219 & 0.120 \\
\hline K & Employee is practicing at home & 0.017 & 0.834 & 0.090 \\
\hline \multirow[t]{3}{*}{$\mathrm{L}$} & $\begin{array}{l}\text { Time horizon of learning (short vs long } \\
\text { time) }\end{array}$ & 0.094 & -0.069 & -0.475 \\
\hline & $\%$ of variance & $33 \%$ & $15 \%$ & $10 \%$ \\
\hline & Name of the factor & 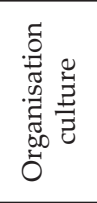 & 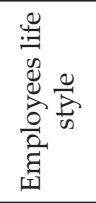 & 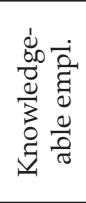 \\
\hline
\end{tabular}

Tab. 3: Resultant factors by method Varimax

The second factor revealed describes completely different type of employee approach to education and learning. In this case, education and learning is not supported or organised by organisation, but it is internal motivation of employee which drives learning. Education is perceived as interesting and fulfilling, because employee works in the area of his/her 
interest and therefore it is no problem to continue in learning and practicing at home. It seems that this kind of employees is strongly interested in the area of their work. Also, the analysis revealed that those employees are not strongly interested in learning and education itself, neither they chosen their job position in order to learn, nor focused on long term or continuous learning. But we may see an influence of support by intangible rewards and set of specific goals in learning. Therefore we may conclude that this group is interested in what they are doing and the want to do their best - as their life style.

The third factor is the extreme of employees who are really interested in education, learning and growth. Such group is probably key employees, knowledgeable employees or talents. They are focused on their career, choose their job because of possibility to learn and grow, they are motivated by internal initiative and they work on their education in long period constantly. To keep such employees in organisation is a crucial factor of future development of organisations. But there is a risk of losing them, because those employees know their value and they can easily migrate (Linhartová, 2012b). This is validated also by choosing their job because of the possibility to learn. It is also possible to see that the third group of employees is not influenced by any kind of rewards or organisational goals; they work on their own learning and growth because they want to.

\section{Evaluation of research questions}

Based on the outputs of the survey and analyses we may conclude that the overall level of education and learning in Czech organisations (Q1) is satisfactory. Two third of employees are educated at work and one third of them are constantly and specifically supported by organisations. Employees are motivated $(\mathrm{Q} 2)$ by organisations only in one third of the cases.
Most of the organisations do not support employee motivation at all. Luckily, most of the employees are motivated internally. And finally (Q3), education and learning is mainly (in 63\% of cases) long-term process. But this result is related only to employee willingness to learn and grow. Thus it does not mean that $63 \%$ of Czech organisations are constantly focusing on lifelong learning and career planning. As previous results states, it is $33 \%$ of them. The rest is approach of employees. On the other hand, $23 \%$ of organisations use only short-term goals and single-purposed training or courses.

\section{Discussion}

As it was mentioned in theoretical background of the paper, Colvin (2010) and other authors stated, that tangible rewards are destroying internal motivation to learn. The Tab. 1 and Tab. 3 support the presumption. According to the results of the survey, employees were not motivated, when education and learning was an organisational "rule" and it was rewarded (factor 1 in Tab. 3). On the other hand, employees grouped by factor 2 and factor 3 (Tab. 3) were acting in the opposite way. Their education, learning and growth was not rewarded or remunerated in any way, but still, they were motivated to continue and they were willing to practice in their free time (factor 2 of Tab. 3) or to work on their growth in long period; to choose specific job positions in order to learn and grow and they were really focused on their development and growth (factor 3 of Tab. 3).

\section{Conclusion}

Education and learning in organisations was surveyed among employees. As education level in organisations is necessary to prognosis of future development, the main approaches to education and learning was searched. 
Association analysis revealed different approaches to employee learning and development. It is possible to find self-motivated (talented) employees and also supportive (learning) organisations which try to develop their employees. Additionally, cooperation of both sides was also found. However sometimes the organisation invest much more than it is possible to gain back from the employees' development. In that case all depends on the recruitment of quality employees who will use the chance offered by organisation. Still, the good result is that it is possible to find talents and knowledgeable employees in the population. Additionally, the assumption that intangible rewards supports and develops learning and development and tangible rewards (money) works in the opposite direction demotivation was confirmed.

According to the results of the factor analysis, three possible approaches to education and learning were found. The three approaches characterize $58 \%$ of surveyed employees. Firstly learning organisations were revealed. Thus employees are educated because of already existing practices and goals inside the organisation. 33\% of employees are continuously educated because of organisations, no matter whether they wish to learn and grow or not. Secondly, a group of employees who chooses to be educated in the area of their interest was found. They work on their own development separately from the organisation. The organisation does not support them in any way. And the third approach can be described as knowledgeable employees. They do everything they can to learn and grow. It is their career and their long term goal. They choose job positions in order to learn constantly.

We may say that the results indicate overall good quality of learning and development in organisations. Basically two thirds of employees are constantly developed. Not just that they mentioned they would like to, but they really are and it is either part of their job or they work on their own education and growth by choosing specific job positions, practicing on their own or work on their career in long period of time.

\section{Acknowledgements}

Supported by University of Economics and Management.

\section{References}

Anderson, V. (2009) Research Methods in Human Resource Management, London: Chartered Institute of Personnel Development.

Chwaszcz, O. (2011) 'The end of black box: the new view of management structures' (in Czech), Scientia et Societas, vol. 7, no. 3, pp. 70-78.

Colvin, G. (2010) Talent makes no difference (in Czech), Brno: Computer Press.

Covey, S. R. (2011) 7 habits of really successful people (in Czech), Prague: Management Press.

Disman, M. (2008) How to obtain sociological knowledge (in Czech), Prague: Karolinum.

Gosling, S. D., Rentfrow, P. J. and Swann, W. B. (2003) 'A very brief measure of the Big-Five personality domains', Journal of Research in Personality, vol. 37, no. 1, pp. 504-528.

Hayes, N. (1998) Fundamentals of social psychology (in Czech). Prague : Portál.

Horváthová, P. (2011) Talent management, Prague: Wolters Kluwer ČR. 
Jablonský, J. (2011) 'Models for Efficiency Evaluation in Education', Proceedings of the 8th International Conference on Efficiency and Responsibility in Education (ERIE 2011), Prague, pp. 110-119.

John, O. P., Naumann, L. P. and Soto, C. J. (2008) 'Paradigm Shift to the Integrative Big-Five Trait Taxonomy: History, Measurement, and Conceptual Issues', Handbook of personality: Theory and research, New York: Guilford Press.

Knight, S. (2011) NLP in praxis (in Czech). Prague: Management Press.

Königová, M. and Fejfar, J. (2011) ‘Evaluation and development of managerial competencies', Scientific papers of the university of Pardubice, vol. 10, no. 4, pp. 68-80.

Linhartová, L., (2012a) 'Transfer of employees as a way of career development' (in Czech), Trendy ekonomiky a managementu, vol. 6, no. 10 , pp. $68-76$.

Linhartová, L. (2012b) 'Variability of Employees' Behaviour during Disaffection', Ekonomický časopis, vol. 60, no. 1, pp. 83-97. Maslow, A. (1943) 'A theory of human motivation', Psychological Review, vol. 50, no. 1, pp. 370-396.

Maxwell, J. C. (2012) 5 levels of leadership (in Czech), Prague: BETA.

Mazouch, P. and Fischer, J. (2001) 'Adult Education Survey as Useful Additional Data Source for Human Capital Analyses and Prognoses', Proceedings of the 8th International Conference on Efficiency and Responsibility in Education (ERIE 2011), Prague, pp. 215-220.

Meyer, J.P. and Allen, N.J. (1991) 'A three-component conceptualization of organizational commitment', Human Resource Management Review, vol. 6, no. 1, pp. 61-89.
Michela, J. L. (2007) 'Understanding employees' reactions on supervisors' influence behaviours', International Journal of Organizational Analysis, vol. 15, no. 4, pp. 322-340.

Mráček, K. (2009) 'State and company solution of effects of current economic crisis' (in Czech), Scientia et Societas, vol. 5, no. 4, pp. 17-33.

Peters, T. (2011) Small big things (in Czech), Prague: Management Press.

Ramlall, S. J. (2004) 'A Review of Employee Motivation Theories and their Implications for Employee Retention within Organizations', The Journal of American Academy of Business, Cambridge, vol. 5, no. 1, pp. 52-63.

Vostrá, H., Jindrová, A. and Dömeová, L. (2011) 'The Position of the CR among the EU States Based on Selected Measures of the Lisbon Strategy', Journal of Competitiveness, vol. 11, no. 3. pp. 50-57.

Vronský, J. (2012) Professiography and its practical usage in human resources in organisation (in Czech). Prague: Wolters Kluwer ČR. Xin J. et al. (2011) 'Constructing a decision support system for management of employee turnover risk', Information, Technology and Management, vol. 12, no. 12, pp. 187-196.

Zeman, K. (2009) 'The fight with poverty risk as a key factor of EU social policy' (in Czech). Scientia et Societas, vol. 5, no. 4. 98-124. 